DOI 10.37882/2223-2982.2020.06-2.24

\title{
ИСПОЛЬЗОВАНИЕ АУТЕНТИЧНЫХ МАТЕРИАЛОВ НА УРОКАХ ИНОСТРАННОГО ЯЗЫКА В ВЫСШЕЙ ЭКОНОМИЧЕСКОЙ ШКОЛЕ
}

\section{USE OF AUTHENTIC LEARNING MATERIALS DURING FOREIGN LANGUAGE LESSONS AT UNIVERSITIES OF ECONOMICS}

\section{P. Rostovtseva}

Summary: The article highlights the problems of using authentic professionally oriented learning materials during foreign language lessons at Universities of Economics. The author considers the concepts, functions and requirements for selecting authentic professionally oriented materials and examples of lessons with authentic materials in the classroom are given.

Keywords: foreign language, University of Economics, authentic materials, motivation.
Ростовцева Полина Петровна

К.n.н., дочент, ФГБОУ ВО «Финансовый университет при Правительстве Российской Федерации» (2. Москва) Rostovtseva_75@mail.ru

Аннотация: В статье освещены проблемы использования аутентичных профессионально ориентированных материалов на уроках иностранного языка в высшей экономической школе. Автор рассматривает понятия, функции и требования при отборе аутентичных профессионально ориентированных материалов, а так же представлены примеры работы с аутентичными материалами на занятиях.

Ключевые слова: иностранный язык, экономический вуз, аутентичные материалы, мотивация.

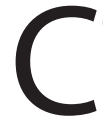
оциальные, экономические и политические изменения, происходящие в мире, все чаще приводят к решительному пересмотру роли иностранного языка в образовании нашей страны. Все эти изменения качественно меняют приоритеты в работе преподавателей высшей экономической школы. Сейчас это актуальная проблема преподавания. Как известно целью обучения иностранного языка, как в экономическом вузе, так и в любом другом вузе является формирование коммуникативной компетенции, которая включает в себя языковую и социокультурную компетенцию. Все эти основы гармонично формируют личность и приближают к межкультурной и языковой коммуникации.

В связи с новыми задачами, преподаватель иностранного языка должен приобщить студентов к иноязычной культуре и эффективному участию в диалоге культур. Для этого на занятиях стоит выбирать такие формы работы, которые смогут обеспечить активное участие каждого учащегося, не смотря на его уровень и способности восприятия информации, которые будут стимулировать его речевые и слуховые способности, а так же формировать интерес к изучаемому языку [7].

Для решения этих задач, на уроках иностранного языка необходимо использовать аутентичные профессионально направленные материалы. Исследуя работы ряда авторов, таких как Кричевская К.С., Мильруд О.П., Носович Е.В., Воронина Г.И. и др., можно сделать выводы, что использование аутентичных профессионально направленных материалов повышает познавательный интерес к изучаемому языку, расширяет лингвострановедческие познания и положительно влияет на личностно-эмоциональное состояние студентов [4].

Освещая тему данной статьи, хотелось бы выделить следующие аспекты исследования:

- Объектом исследования является процесс обучения иностранному языку в высшей экономической школе.

- Предметом исследования является аутентичный профессионально направленный материал.

При изучении данной темы была выдвинута следующая гипотеза: системное применение аутентичного профессионально направленного материала становится эффективным средством повышения качества обучения иностранного языка.

Целью данной статьи является раскрытие эффективности употребления аутентичного профессионально направленного материала на занятиях иностранного языка.

В последнее время все больше уделяется внимание аутентичности в методике преподавания иностранного языка в высшей школе. Если разобраться, «аутентичный» (authentic) означает «подлинный, достоверный» в переводе с английского языка. Это определение используют для характеристики текстов, аудио фрагментов и других материалов, используемых на занятиях иностранным языком. Хотя существуют некоторые проблемы исполь- 
зования аутентичных материалов.

Для начала попробуем разобраться, что же такое аутентичные материалы. Автор Кричевская К.С. дает следующее определение: Аутентичные материалы - это материалы, взятые из оригинальных источников, которые характеризуются естественностью лексического наполнения и грамматических форм, ситуативной адекватностью используемых языковых средств, иллюстрирует случаи аутентичного словоупотребления, и которые, хотя и не предназначены специально для учебных целей, но могут быть использованы при обучении иностранному языку [4].

Кричевская К.С. относит к этому термину подлинные литературные произведения, изобразительное искусство, фольклор, музыкальные произведения и все предметы реальной действительности, такие, как одежда, мебель, посуда и их графический образ.

Предметы ежедневного обихода формируются в самостоятельную группу - прагматичные материалы (такие как газеты, вывески, реклама, меню и др.), они очень доступны и как правило приобщают к естественной среде гораздо ближе, чем иные текстовые материалы.

К аутентичным можно отнести аудио и видео материалы. Это могут быть радио, телевидение, объявления в транспорте и вокзалах и даже озвучивание автоинформатора сотовых операторов. Применение таких материалов на занятиях является крайне важным, поскольку глубже погружает в среду изучаемого современного иностранного языка и повышает интерес к культуре [4].

По градации применения в сферах употребления, аутентичные материалы можно разграничить на [5]:

- учебно-профессиональные;

- экономические;

- социально-культурные;

- спортивные;

- семейно-бытовые.

Аутентичные материалы так же делятся на несколько функций.

- Информационно-обучающая функция выражает речевой образец (с помощью интонации, произношения, грамматических основ), помогает более естественно воспринять информацию речевого общения, несмотря на пространственно временные рамки реального или воображаемого образа описанного в тексте (например, произведение «Гарри Поттер» является отличным образцом современного английского языка, несмотря на то, что жанр этой книги является фантастикой).

- Организующе-управляющая функция выражается в некоем «эффекте присутствия» или «участия», развивает речевую активность и обеспечивает огромный мотивационный потенциал.

- Интегративная функция служит связкой между частями занятий и помогает упорядочить структуру аутентичного материала.

- Иллюстративно-наглядная функция представляет собой единство всех видов наглядности (зрительной, языковой, слуховой, образной, моторной, предметной, ситуативно-модельной, смешанной и др.), является эффективным средством дистанционного погружения в естественную среду на всех уровнях обучения.

- Развивающая функция проявляется в активизации познавательной деятельности студентов, развивает внимание, воображение, самостоятельность, наблюдательность, мышление, закрепляет языковую память и умения во всех видах речевой деятельности. В целом, это творческая деятельность, которая проецируется переносом знаний и умений в новую ситуацию.

- Воспитательно-эвристическая функция формирует у учащихся чувство уважения к культуре и народу страны изучаемого языка. Является вспомогательным элементом в восприятии чужих стереотипов, возникающих при изучении другой культуры (ведется путем сравнения двух культур, родной и страны изучаемого языка).

Прежде чем использовать аутентичный материал в работе к нему необходимо предъявить определенные требования, поскольку он может оказаться слишком сложным, даже для подготовленного студента со знанием второго языка. В этом кроется определенная трудность в работе, поскольку текст нельзя исправить или упростить, он потеряет истинную подлинность и, столкнувшись с определенной ситуацией в жизни, можно упустить суть слов или происходящего, другая причина - это колоссальная потеря времени при подготовке самого преподавателя к занятию. И наконец - это чувство победы обучаемого перед трудностью понимания, преодолев которые мотивация к изучению иностранного языка станет еще выше, а это способствует лучшему усвоению и закреплению информации $[9,10]$.

Какие факторы стоит учитывать при подборе аутентичных материалов:

- возрастные особенности учащихся;

- подлинность представленной ситуации;

- понимание разных форм речи;

- эмоциональный отклик;

- новизна информации.

Информацию можно разделить на 3 уровня сложности: - способности ниже среднего уровня (на данном этапе лучше использовать общедоступную и повсеместно распространенную информацию, на- 
пример расписания, меню, билеты, реклама, погода);

- средний уровень (это могут быть газеты, сводки новостей);

- продвинутый (достижение понимания происходит без затруднений, это может касаться прочтения научных статей) [4].

Часто встречается, что студенты стараются избегать работы с аутентичным материалом, поскольку он вызывает трудности с пониманием из-за встречи с большим количеством неизвестных слов. Но лучше всего дать дочитать текст и по контексту догадаться, о чем идет речь. Важно дать понять, что все знать невозможно, но если проявить смекалку, включить языковую догадку, то все трудности можно преодолеть. Эти упражнения очень стимулируют и мотивируют обучающихся, приближают их к реальной действительности и дарят чувство уверенности в нестандартной ситуации [2].

Хотелось бы поделиться некоторыми примерами работ с аутентичными материалами на уроках иностранного языка.

\section{Работа с газетами и статьями:}

1. Группа делится на несколько команд, каждая из которых получает газету и список вопросов. Побеждает та команда, которая даст большее количество ответов из газет за отведенное время.

2. Группа делится на несколько команд, каждая из которых получает газету. Выбирается одна статься, каждая команда читает ее и составляет список вопросов к ней, далее команды обмениваются вопросами и стараются найти ответы к ним из выбранной статьи.

3. Можно предложить описать новость, опираясь на картинку.

4. Предложить прочитать заголовок и составить прогноз, о чем будет идти речь в данной статье.

5. Либо прочитав текст статьи, предложить ей яркое название [5].

\section{Работа с письмом.}

Работа с письмом является очень полезным и практичным занятием, поскольку в реальной жизни часто приходится сталкиваться с различной формулировкой текстов и документов (это касается анкет, деловых писем, характеристик и пр.) [3].

Ознакомившись с различными формами письма на занятиях, предложите ответь на вопросы: как начать письмо, где пишется дата, как оформить письмо, какими фразы допустимы, можно ли делать сокращения в письме, по какому принципу текст делится на абзацы, как заканчивается письмо, чем отличается официальное письмо от неофициального, выясните характер письма (деловое, личное, проблемное, письмо - поздравление, письмо - приглашение, письмо благодарность).

Работа с текстом (чтение):

- чтение с общим пониманием (прочитав текст, сказать, о чем он, он какого лица и т.д.);

- чтение с частичным извлечением информации (прочитать текст и ответить на вопросы);

- чтение с полным пониманием (прочитать текст, ответить на вопросы, закончи предложение, сказать верно ли предложение, исправить в случае необходимости, соотнеси начало и конец предложения, пересказать текст) [6,8].

Работа с грамматическим материалом:

1. Предложить текст, выписать из него все глаголы, прилагательные, образовать степени сравнения, определи видовременную форму.

2. Предложить текст и переписать абзац, заменив прилагательные (глаголы) на синонимы, найти предложения в определенном времени.

3. Предложить текст, исправь ошибки, задать вопросы по тексту.

4. Предложить текст и пересказать его в косвенной речи.

5. Предложить текст и трансформировать предложения в пассивный залог.

Все предложенные варианты можно совмещать или менять по необходимости.

\section{Работа с аудиозаписями}

Интересна работа с переводом популярных песен, в них очень часто используются новые обороты, которые в полной мере отражают аутентичность изучаемого языка.

\section{Работа с видео материалом}

Для полного погружения в культуру и быт страны изучаемого языка необходимо иметь не только хорошие практические и грамматические знания и умения, а и иметь представление о языке тела (Body Language), пронаблюдать за жестами, мимикой, знать, какая дистанция должна соблюдаться при общении (зона комфорта) $[7,1]$. В этом помогут небольшие видеоролики, которые можно смотреть, как со звуком, так и без звука. Студентам можно предложить несколько несложных, но весьма эффективных упражнений с использованием видеороликов:

1. Например можно просмотреть видео без звука для того, чтобы сымитировать поведение, общение того или иного персонажа. После чего преподаватель дает свой комментарий и необходимые пояснения. 
2. Просмотрев сюжет с интервью нескольких людей, можно задать ряд вопросов, например: сколько лет персонажу, какой он по характеру, какое у него образование, род деятельности и т.д.

3. Просматривается видео отрывок, после чего предлагается переложить происходящее действие или ситуацию на себя и прокомментировать свое отношение к происходящему.

4. Просматривается отрывок с диалогами нескольких людей. Видео-ролик периодически останавливается, для того, чтобы учащиеся смогли спрогнозировать ответ действующего лица. Это упражнение очень развивает интуицию и способствует развитию информационного поиска.

5. Предлагается посмотреть фрагмент рекламы и понять, о каком продукте или предмете шла речь.

6. При просмотре сюжета предлагается ответить на 5 основных вопросов: Кто? Что? Где? Когда? Почему? Как? Данная формулировка эффективна при просмотре новостей или исторической хроники.

7. Просмотру предлагается документальный фильм. Группа студентов делится на пары, кото- рым преподаватель в начале просмотра предоставляет список вопросов освещенных в фильме (это могут быть имена, даты или названия). Задача студентов - набрать максимальное количество баллов за правильные ответы.

8. Обучающимся предлагается просмотреть видео сюжет и составить план, по которому они смогут в хронологическом порядке воспроизвести все события просмотренные ранее.

9. Перед просмотром видео ролика, преподаватель может задать вопрос, касающийся определенной информации, которую необходимо найти при просмотре (например, имена, место или даты).

В заключении хотелось бы сказать, что использование аутентичных материалов на уроках иностранного языка в высшей экономической школе, несмотря на сложности и специфику обработки информации, способствует повышению мотивации к изучению иностранного языка, развивает языковую догадку и формирует иноязычную культурологическую компетенцию.

\section{ЛИТЕРАТУРА}

1. Бердина И.В. использование короткометражных фильмов и сериалов в преподавании иностранного языка (на примере преподавании немецкого языка в неязыковых вузах) //Теория и практика обучения иностранным языкам в неязыковом вузе: традиции, инновации, перспективы. (борник научных трудов. Москва. 2014.

2. Ванягина М.Р. Формирование социокультурной компетенции у курсантов военных вузов в процессе изучения английского языка: автореф. дисс ... канд. пед. н. Екатеринбург, 2010. 23с.

3. Гальскова Н.Д., Гез Н.И. Теория обучения иностранным языкам. Лингводидактика и методика. Учебное пособие. 3-е изд., стер. М.: Академия, 2016. $336 \mathrm{c}$.

4. Кричевская К.С. Прагматические материалы, знакомящие учеников с культурой и средой обитания жителей страны изучаемого языка // Иностранные языки в школе. 1996. №1. С.13-17.

5. Носонович Е.В., Мильруд Р.П. Параметры аутентичного учебного текста // Иностранные языки в школе. 1999. №1. С.18-23.

6. Ростовцева П.П., Гусева Н.В., Соболева О.С. Оптимизация профессионально ориентированной иноязычной речевой подготовки студентов неязыковых вузов // Педагогика и психология образования. 2016. № 4. С. 78-83.

7. Сафонова В.В. Соизучение языков и культур в зеркале мировых тенденций развития современного образования // Язык и культура. 2016. №1 (25). C.123-141.

8. Gebhard J.G. Teaching English as a Foreign Language: A Teacher Self-Development and Methodology Guide. Ann Arbor: The University of Michigan Press, 1996.

9. Melnichuk M.V., Osipova V.M. Cooperative learning as a valuable approach to teaching translation // XLinguae. 2017. T. 10. № 1. C. 25-33.

10. Suarez Sierra, Lucia (2013). The incidence of using authentic material in teaching vocabulary to students who are attending 10th grade at saint patrick school in Quito-Ecuador from september to december 2012. Applied Linguistics in English Career. ESPE. Sede Quito.

(c) Ростовцева Полина Петровна (Rostovtseva_75@mail.ru). 